\title{
HUBUNGAN TINGKAT PENGETAHUAN TENTANG COVID-19 DENGAN KEPATUHAN PENGGUNAAN ALAT KONTRASEPSI SUNTIK PADA AKSEPTOR KB SUNTIK
}

\author{
Warsini, Sri Aminingsih \\ STIKES PANTI KOSALA, Sukoharjo, Jawa Tengah, Indonesia
}

\begin{abstract}
Abstrak
Latar belakang : jumlah penduduk dunia semakin meningkat. Di Indonesia, menurut perhitungan BPS tahun 2015, jumlah penduduk Indonesia adalah 255.461.700, atau $3,49 \%$ dari jumlah penduduk dunia. Indonesia juga diprediksi akan mendapatkan bonus demografi pada tahun 2025-2035 dan menjadikan Indonesia sebagai negara terpadat keempat di dunia. Untuk itu diperlukan upaya pengendalian laju pertumbuhan penduduk melalui program Keluarga Berencana dengan menggunakan alat kontrasepsi dalam penatalaksanaan persalinan, salah satunya adalah suntik. Namun, selama pandemi Covid-19 terjadi penurunan kepatuhan penggunaan alat kontrasepsi.

Tujuan : mengetahui hubungan tingkat pengetahuan tentang Covid-19 dengan kepatuhan penggunaan alat kontrasepsi suntik akseptor KB suntik di Desa Kemasan Kabupaten Sukoharjo.

Subjek dan metode: jenis penelitian ini adalah penelitian analitik observasional dengan desain korelasional melalui pendekatan retrospektif. Populasi penelitian adalah seluruh 40 akseptor KB suntik periode Desember 2020 sampai Maret 2021 di Desa Kemasan yang berusia kurang dari 45 tahun. Teknik pengambilan sampel yang digunakan adalah jenuh. Data dianalisis menggunakan Uji Chi Square.

Hasil : mayoritas tingkat pengetahuan responden tentang Covid-19 rendah yaitu $72,5 \%$ dan kategori tinggi $27,5 \%$, kepatuhan akseptor KB suntik mayoritas tidak patuh yaitu $75 \%$ dan sebanyak $25 \%$. responden patuh. Ada hubungan antara tingkat pengetahuan tentang Covid-19 dengan kepatuhan penggunaan kontrasepsi suntik akseptor KB suntik $(p<0,001)$.

Kesimpulan : ada hubungan antara tingkat pengetahuan tentang Covid-19 dengan kepatuhan penggunaan alat kontrasepsi suntik akseptor KB suntik di Desa Kemasan Kabupaten Sukoharjo $(p<0,001)$.
\end{abstract}

Kata kunci: Covid-19, keluarga berencana, kepatuhan, pengetahuan, suntik

\section{THE RELATIONSHIP BETWEEN THE LEVEL OF KNOWLEDGE ABOUT COVID-19 WITH COMPLIANCE WITH THE USE OF INJECTION CONTRACEPTIVES FOR INJECTION FAMILY PLANNING ACCEPTORS}

\author{
Warsini $^{1}$, Sri Aminingsih ${ }^{2}$
}

\begin{abstract}
Background : the population in the world is increasing. According to BPS calculations in 2015 in Indonesia, the total population of Indonesia is $255,461,700$, which is $3.49 \%$ of the world's population. Indonesia is also predicted to receive a demographic bonus in 20252035 and this makes Indonesia the fourth most populous country in the world. For this reason, efforts are needed to control the population growth rate through the Family Planning program by using contraceptives in managing births, one of which is injections. However, during the Covid-19 pandemic, there was a decline in compliance with the use of contraceptives.

The aim of the study : to determine the relationship between the level of knowledge about
\end{abstract}


Covid-19 and the compliance with the use of injection contraceptives for injection family planning acceptors in the village of Kemasan, Sukoharjo Regency.

Subjects and Methods : This type of research is an observational analytic study with a correlational design through a retrospective approach. The population of the study was all 40 acceptors of injection family planning from December 2020 to March 2021 in Packaging Village who were less than 45 years old. The sampling technique used was saturated. Data were analyzed using Chi Square Test.

Results : the majority of respondents' knowledge level about Covid-19 was low, namely $72.5 \%$ and $27.5 \%$ in the high category, the majority of acceptors obedience in implementing injection family planning is not obedient, namely $75 \%$ and as many as $25 \%$ of respondents are obedient. There is a relationship between the level of knowledge about Covid-19 and compliance with injection contraceptive use for injection family planning acceptors $(p<0.001)$.

Conclusion : there is a relationship between the level of knowledge about Covid-19 with compliance with the use of injection contraceptives for injection family planning acceptors in the village of Kemasan, Sukoharjo Regency $(p<0.001)$.

Keywords: compliance, Covid-19, family planning, injection, knowledge

Korespondensi: Warsini. Program Studi D3 Keperawatan STIKES PANTI KOSALA. JI. Raya Solo-Baki KM. 4 Gedangan, Solo Baru, Sukoharjo, Jawa Tengah. Email: warsinimulyono@gmail.com.

\section{PENDAHULUAN}

Jumlah penduduk di dunia semakin meningkat, menurut Ariana (2017), proyeksi laporan PBB menunjukkan bahwa populasi dunia saat ini adalah 7,3 miliar dan diperkirakan akan mencapai 8,5 miliar pada tahun 2030, kemudian 9,7 miliar pada tahun 2050 dan 11,2 miliar pada tahun 2100 . Laporan ini juga memproyeksikan bahwa tahun 2050, populasi dari enam negara diperkirakan akan melebihi 300 juta yaitu negara Tiongkok, India, Indonesia, Nigeria, Pakistan dan Amerika Serikat. Pada tahun 2019, jumlah penduduk dunia diperkirakan akan mencapai angka 7,5 miliar jiwa. Di Indonesia sendiri menurut perhitungan BPS (Badan Pusat Statistik) tahun 2015, jumlah penduduk Indonesia sebanyak 255.461.700 jiwa, yaitu 3,49 persen dari seluruh penduduk dunia. Indonesia diprediksi akan mendapat bonus demografi tahun 2025-2035. Artinya, pada rentang tahun tersebut Indonesia berada dalam keadaan jumlah penduduk usia produktif lebih besar dari jumlah penduduk nonproduktif. Hal ini menjadikan negara Indonesia adalah negara yang berpenduduk nomor 4 di dunia. Jumlah penduduk ini diperkirakan akan meningkat karena menurut Khomsan, et al (2020), mengatakan angka kelahiran masih tinggi yaitu sekitar 4,5 juta bayi lahir pertahun serta pertumbuhan penduduk yang tidak merata.

Laju pertumbuhan penduduk bisa dikendalikan dengan pencanangan program Keluarga Berencana (KB). Menurut Jitowiyono dan Rouf (2019), tujuan utama KB adalah untuk menjarangkan kehamilan karena berkaitan erat dengan kesehatan dan kesejahteraan ibu dan anak. KB disatukan dengan kesehatan dengan harapan jumlah akseptor mencapai 3 juta selama 5 tahun sehingga dapat mencegah 600.000 700.000 angka kelahiran. Menurut Siswosuharjo dan Chakrawati (2010), kontrasepsi merupakan upaya untuk menunda kehamilan karena berbagai alasan dan terdiri dari beberapa cara yang bisa 
dilakukan, salah satunya adalah kontrasepsi hormonal. Kontrasepsi hormonal merupakan kontrasepsi yang menggunakan hormon yaitu pil $K B$ kombinasi, suntik $K B$, susuk $K B$ dan IUS (Intra Uterine System). Menurut penelitian Muslima dan Herjanti (2019), kontrasepsi hormonal yang paling banyak digunakan di Indonesia adalah jenis KB suntik karena kerjanya yang efektif, pemakaiannya yang praktis, harganya relatif murah dan aman. Kontrasepsi suntik memiliki resiko kesehatan yang sangat kecil, tidak berpengaruh pada hubungan suamiistri. Keuntungan atau manfaat kontrasepsi suntik diantarannya tidak memerlukan pemeriksaan dalam, klien tidak perlu menyimpan obat, jangka panjang dan efek sampingya sangat kecil. Kepatuhan yang dimiliki para akseptor KB khususnya akseptor KB suntik, pada dasarnya dipengaruhi oleh kesadaran dari pemakaian serta dukungan keluarga, terutama suami yang mana dapat menjadi suatu motivasi bagi akseptor suntik.

Kontrasepsi suntik hanya dapat mencegah kehamilan dalam jangka waktu tertentu yaitu 1 bulan dan 3 bulan sehingga harus diulang. Menurut Andalas (2014), mengatakan seseorang yang mengunakan kontrasepsi KB suntik harus dilakukan secara terus menerus. KB suntik 1 bulan dilakukan setiap 1 bulan sekali dan KB suntik 3 bulan, dilakukan 3 bulan sekali. Tindakan pemberian suntikan ini juga harus dilakukan oleh petugas kesehatan yang berwenang. Tindakan penyuntikan yang terus-menerus ini mengharuskan para akseptor KB suntik untuk selalu datang ke pelayanan kesehatan di mana petugas kesehatan berada. Hal ini menjadi rumit karena adanya situasi pandemi Covid-19 yang sedang berlangsung hingga saat ini.
Virus Corona adalah virus yang penyebarannya sangat cepat. Covid-19 atau yang sering kita dengar virus corona adalah virus yang menyerang sistem pernapasan. Covid-19 ini pertama kali ditemukan di Wuhan, China. Virus corona menular dengan sangat cepat dan telah menyebar sampai ke beberapa negara termasuk Indonesia (Nasruddin dan Haq, 2020).

Sejak kasus Covid-19 pertama yang dilaporkan di Wuhan, China pada akhir tahun 2019, Covid-19 dengan cepat menyebar ke seluruh Tiongkok dan juga melibatkan banyak negara lain meskipun ada upaya global untuk mencegah penyebarannya. Menurut laporan WHO (World Health Organization atau Organisasi Kesehatan Dunia), Covid-19 telah mempengaruhi 85.403 pasien di 57 negara dan telah menyebabkan 2.924 kematian sampai dengan tanggal 29 Februari 2020 , di mana sekitar $92,9 \%$ kasus dan $97,1 \%$ kematian telah terjadi, berada di Tiongkok. Menurut Pusat Kontrol dan Pencegahan Penyakit Tiongkok $81 \%$ pasien dengan Covid-19 memiliki kasus ringan dan $87 \%$ berusia $30-79$ tahun. Selain itu, $3,8 \%$ dari mereka dengan Covid-19 adalah tenaga kesehatan. (Daud, ed., 2020).

Menurut Sudarsana, ed., (2020), mayoritas negara di dunia terkena pandemi Covid-19, Amerika menjadi negara dengan kasus tertinggi Covid-19 disusul Brazil, Rusia, Spanyol dan Britania Raya. Indonesia sendiri berada di urutan 32 dengan 25.216 kasus, pasien meninggal 1.520 dan sembuh 6.492 orang. Indonesia menjadi negara tertinggi ke-2 kasus positif Covid-19 di Asia Tenggara di bawah Singapura.

Menurut Kemenkes RI (2020), pada pertengahan bulan April 2020 jumlah penderita Covid-19 mencapai 5.923 yang dinyatakan 
positif. Mengingat banyaknya angka kejadian Covid-19 di Indonesia yang menyebabkan angka kematian cukup tinggi membuat masyarakat menjadi takut untuk datang ke pelayanan kesehatan mengingat tenaga kesehatan adalah salah satu golongan yang rentan untuk membawa dan menyebarkan virus ini. Di sisi lain para akseptor KB juga harus melakukan penyuntikan ke pelayanan kesehatan secara rutin. Hal ini mengingat belum semua akseptor memahami terjadinya pencegahan Covid-19. Menurut penelitian Aqmal (2020), menyebutkan masyarakat kurang berpartisipasi aktif dalam menjalankan program KB karena adanya pandemi Covid-19 dan faktor-faktor yang mempengaruhi kepatuhan yaitu pengetahuan, kecemasan dan ketakutan. Penelitian menurut Qadaruddin (2020) juga menyebutkan bahwa pengetahuan masyarakat tentang pencegahan Covid-19 memiliki peranan penting dalam keteraturan penggunaan alat kontrasepsi suntik sehingga merekomendasikan supaya masyarakat mengenal, mempelajari dan memahami segala aspek dari penyakit Covid-19 termasuk tanda dan gejala, penyebab, pencentus dan penatalaksanaannya.

Salah satu kabupaten yang terus giat menggalakkan program Keluarga Berencana adalah Kabupaten Sukoharjo melalui Gerakan Masyarakat (Germas). Berdasarkan hasil observasi salah satu desa dengan akseptor KB yang paling banyak adalah akseptor KB suntik yaitu Desa Kemasan. Desa Kemasan Kecamatan Polokarto mempunyai $70 \mathrm{KK}$ dengan jumlah wanita usia reproduksi lebih dari 70 orang. Hasil wawancara dengan Bidan Desa Kemasan diketahui terdapat sekitar 35 akseptor KB suntik aktif di mana beberapa diantaranya menjadi tidak patuh pada jadwal suntik selama masa pandemi Covid-19 tetapi belum pernah diteliti penyebabnya. Hasil survei awal diperoleh 3 ibu yang mengatakan takut untuk pergi ke pelayanan kesehatan.

Berdasarkan keadaan di atas, maka peneliti tertarik untuk melakukan penelitian dengan judul "Hubungan Tingkat Pengetahuan tentang Corona Virus Disease dengan Kepatuhan Pengunaan Alat Kontrasepsi Suntik pada Akseptor KB Suntik di Desa Kemasan". Penelitian ini berbeda dengan penelitian serupa terdahulu di mana penelitian ini terjadi pada masa pandemi yang sudah berlangsung selama 8 bulan, sehingga memungkinkan adanya pengaruh terhadap kepatuhan para akseptor KB suntik yang mana kondisi tersebut belum pernah diteliti.

\section{TUJUAN PENELITIAN}

Untuk mengetahui hubungan tingkat pengetahuan tentang Covid19 dengan kepatuhan penggunaan alat kontrasepsi suntik pada akseptor KB suntik di Desa Kemasan Kabupaten Sukoharjo.

\section{METODE/DESAIN PENELITIAN}

Jenis penelitian ini adalah analitik observasional dengan desain korelasional melalui pendekatan retrospektif. Data yang diperoleh dianalisis menggunakan Uji Chi Square.

\section{POPULASI, SAMPEL DAN TEKNIK SAMPLING}

Populasi penelitian adalah semua akseptor KB suntik pada bulan Desember 2020 sampai Maret 2021 di Desa Kemasan yang berusia kurang dari 45 tahun sebanyak 40 akseptor. Teknik sampling yang digunakan adalah jenuh. 
HASIL PENELITIAN berikut:

Hasil penelitian ini adalah

Tabel 1.

Karakteristik Responden

\begin{tabular}{lcc}
\hline \multicolumn{1}{c}{ Karakteristik } & $\mathrm{n}$ & $\%$ \\
\hline Usia Responden (thn) & & \\
$20-35$ & 25 & 62,5 \\
$36-45$ & 15 & 37,5 \\
Tingkat Pendidikan & & \\
SD/sederajat & 14 & 35 \\
SMP/sederajat & 21 & 52,5 \\
SMA/sederajat & 4 & 10 \\
Diploma III & 1 & 2,5 \\
Jumlah Anak & & \\
1 & 14 & 35 \\
2 & 18 & 45 \\
3 & 8 & 20 \\
Tingkat Pengetahuan & & \\
Rendah & 29 & 72,5 \\
Tinggi & 11 & 27,5 \\
Kepatuhan KB & & \\
Patuh & 10 & 25 \\
Tidak Patuh & 30 & 75 \\
\hline
\end{tabular}

Dari tabel 1 diketahui bahwa :

1. Berdasarkan kriteria usia responden kurang dari 45 tahun maka didapatkan rentang usia responden antara 21 - 45 tahun dengan rata-rata usia 34,63 tahun yang merupakan usia reproduksi, dengan usia terbanyak adalah 20-35 tahun yaitu $25(62,5 \%)$ dan termasuk dalam usia reproduksi sehat.

2. Tingkat pendidikan responden paling banyak adalah lulusan SMP/sederajat, yaitu 21 responden $(52,5 \%)$ dan paling sedikit adalah Iulusan Diploma III yaitu 1 responden (4\%).

3. Jumlah anak paling banyak dimiliki oleh responden adalah 2 anak dengan jumlah responden sebanyak $18(45 \%)$ dan paling sedikit adalah 1 anak dengan jumlah responden adalah 14 (35\%)

4. Mayoritas tingkat pengetahuan responden tentang Corona Virus
Disease termasuk dalam kategori rendah yaitu sebanyak 29 responden $(72,5 \%)$.

5. Sebagian besar responden tidak patuh dalam melaksanakan KB suntik yaitu sebanyak $30(75 \%)$ dan hanya sebanyak 10 responden saja yang patuh dalam melaksanakan KB suntik yaitu 10 responden (25\%).

Tabel 2.

Tabulasi Silang Variabel

\begin{tabular}{lccc}
\hline Tingkat & \multicolumn{2}{c}{ Kepatuhan KB } & \multirow{2}{*}{$p$} \\
\cline { 2 - 3 } Pengetahuan & Patuh & Tidak & \\
\hline Tinggi & 9 & 1 & $<0,001$ \\
Rendah & 1 & 29 & \\
\hline Total & 10 & 30 & \\
\hline
\end{tabular}

Dari tabel 2 hasil analisis Chi Square diketahui terdapat hubungan tingkat pengetahuan tentang Corona Virus Disease dengan kepatuhan penggunaan alat kontrasepsi suntik pada akseptor KB suntik di Desa Kemasan Kabupaten Sukoharjo ( $p$ $<0,001)$.

\section{PEMBAHASAN}

Karakteristik responden menunjukkan bahwa sebagian besar responden berusia antara 2035 tahun yaitu $62,5 \%$. Hal ini sesuai dengan anjuran dari BKKBN (2016) yang menyebutkan bahwa usia yang paling aman untuk melangsungkan kehamilan adalah 20 - 35 tahun atau disebut dengan usia reproduksi sehat sehingga seiring dengan himbauan dari BKKBN itu maka sebagian besar ibu yang mengikuti program KB termasuk dalam rentang usia tersebut. Hal ini sesuai dengan penelitian oleh Muslima dan Herjanti (2019), yang menyebutkan bahwa umur akseptor KB suntik terbanyak adalah umur 20-35 tahun yaitu $75,6 \%$. Sedangkan Diakses dari tingkat pendidikan diketahui bahwa sebagian besar responden lulus SMP/sederajat yaitu $52,5 \%$. 
Hal ini menunjukkan bahwa himbauan Pemerintah untuk meningkatkan taraf hidup melalui sektor pendidikan bagi setiap warga negaranya yaitu melalui pendidikan dasar wajib bagi setiap warga negara 9 tahun yang dapat diasumsikan pendidikan sampai tingkat SMP (Sekolah Menengah Pertama) sudah tercapai. Maka dalam penelitian ini ditemukan bahwa mayoritas responden mempunyai tingkat pendidikan lulus SMP.

Diakses dari karakteristik jumlah anak responden maka diketahui bahwa mayoritas jumlah anak adalah 2 yaitu $45 \%$. Hal ini menunjukkan bahwa responden mengatur jumlah anak mereka dan telah sesuai dengan tujuan pemakaian alat kontrasepsi yaitu untuk menunda kehamilan, menjaga jarak kehamilan serta menghentikan kehamilan (Yuhedi dan Kurniawati, 2013). Program ini juga menjadi tujuan Pemerintah untuk menekan laju pertumbuhan penduduk sehingga dapat mewujudkan Norma Keluarga Kecil Bahagia Sejahtera (NKKBS) sesuai dengan UU No. 10 tahun 1992.

Hasil analisis penelitian ini diketahui bahwa mayoritas tingkat pengetahuan responden tentang Corona Virus Disease termasuk dalam kategori rendah yaitu sebanyak 29 responden (72,5\%). Meskipun masalah Corona Virus Disease ini sudah mendunia dan menjadi sorotan kesehatan namun belum semua penduduk di Indonesia mengetahui dengan jelas tentang penyakit ini. $\mathrm{Hal}$ ini dimungkinkan karena perjalanan penyakit ini yang belum banyak diketahui sehingga sampai saat ini organisasi kesehatan dunia yaitu WHO pun masih berusaha mengendalikan penyebaran penyakit ini. Rendahnya tingkat pengetahuan ini dipengaruhi oleh berbagai hal karena menurut
Notoatmojo (2011) tingkat pengetahuan seseorang dipengaruhi oleh banyak faktor, antara lain tingkat pendidikan, pekerjaan, umur, faktor lingkungan dan faktor sosial budaya. Hasil penelitian ini tidak sejalan dengan penelitian Yanti, et al (2020), yang menyebutkan bahwa 99\% tingkat pengetahuan tentang Corona Virus Disease pada penduduk di Indonesia dalam kategori baik. Hasil ini juga tidak sesuai dengan hasil penelitian di daerah lain di Indonesia, sebagai contoh menurut Purnamasari dan Raharyani (2020) yang menyebutkan tingkat pengetahuan masyarakat tentang Corona Virus Disease di Kabupaten Wonosobo dalam kategori tinggi.

Hasil penelitian juga diketahui bahwa sebagian besar responden tidak patuh dalam melaksanakan KB suntik yaitu sebanyak $75 \%$ dan hanya sebanyak $25 \%$ saja yang patuh dalam melaksanakan KB suntik. Hasil penelitian ini sesuai dengan penelitian menurut Febrianti (2018), diketahui ketidakpatuhan akseptor KB suntik di BPM Murtinawita, Pekanbaru, mencapai $57 \%$. Kondisi ini tentunya perlu mendapat perhatian mengingat berbagai bukti penelitian pada masa sebelum pandemi Corona Virus Disease menunjukkan bahwa akseptor KB suntik sudah patuh terhadap jadwal penyuntikannya. Sebagai contoh hasil penelitian menurut Noriani, et al (2019) menunjukkan kepatuhan akseptor KB suntik di BPM Koriawati, Bali, sebesar 63,2\%. Rendahnya kepatuhan responden dalam melaksanakan suntik KB ini dimungkinkan karena pelaksanaan suntik KB harus dilakukan di fasilitas pelayanan kesehatan dan dilakukan oleh petugas kesehatan, sedangkan saat penelitian dilakukan masih pada masa pandemi sehingga beberapa akseptor menyatakan enggan untuk melaksanakan suntik 
KB dan mengakibatkan tidak sesuai dengan jadwal yang seharusnya. Di sisi lain menurut penelitian Purwanti (2021), diketahui pula bahwa banyak fasilitas kesehatan yang menyediakan suntik KB juga memilih tutup karena keterbatasan APD yang dimiliki untuk petugas kesehatan di fasilitas pelayanan kesehatan tersebut. Hal ini sesuai dengan penelitian menurut Muslima dan Herjanti (2019), yang menyebutkan bahwa kepatuhan melaksanakan KB suntik dipengaruhi oleh pemanfaatan pelayanan kesehatan, peran bidan, peran suami, dan persepsi sebesar $80,7 \%$.

Hasil analisis bivariat menunjukkan bahwa ada hubungan tingkat pengetahuan tentang Covid19 dengan kepatuhan penggunaan alat kontrasepsi suntik pada akseptor KB suntik di Desa Kemasan Kabupaten Sukoharjo ( $p$ $<0,001)$. Pengetahuan merupakan kemampuan intelektual responden yang mencakup pemahaman terhadap materi tertentu. Pengetahuan merupakan proses mencari tahu dimana yang tadinya tidak tahu menjadi tahu. Pengetahuan ini akan membentuk keyakinan sehingga responden akan berperilaku sesuai dengan keyakinan tersebut. Dengan tingkat pengetahuan yang mayoritas rendah maka keyakinan yang membentuk kepatuhan responden untuk melakukan suntik KB sesuai dengan jadwal yang ditetapkan menjadi rendah sehingga mengakibatkan tingkat kepatuhan yang rendah pula. Tingkat pengetahuan seseorang juga bervariasi karena dipengaruhi oleh umur, pendidikan dan media masa atau informasi (Wawan dan Dewi, 2011). Pengetahuan seseorang merupakan dasar melakukan perilaku tertentu. Dalam penelitian ini asumsi peneliti adalah perilaku dalam melaksanakan suntik KB yang harus dilakukan secara berulang sesuai jadwal yang telah ditentukan dan disebut dengan kepatuhan. Kepatuhan adalah sejauh mana perilaku pasien sesuai dengan ketentuan yang diberikan oleh profesional kesehatan maka dalam penelitian ini dimana mayoritas tingkat pengetahuan responden tentang Corona Virus Disease dalam kategori rendah sebesar $72,5 \%$, diikuti pula dengan tingkat kepatuhan dalam melaksanakan KB suntik yang rendah pula yaitu sebesar $25 \%$. Hal ini sesuai dengan penelitian menurut Purwanti (2021), yang menyebutkan bahwa tingkat pengetahuan berpengaruh terhadap kunjungan akseptor KB ke tempat layanan KB. Sebanyak $77,48 \%$ responden penelitian memilih setuju untuk tidak ber-KB di fasilitas pelayanan kesehatan pemerintah yang murah karena berisiko tertular Covid-19. Namun hasil penelitian ini tidak sesuai dengan hasil penelitian Febrianti (2018) yang menunjukkan tidak ada pengaruh antara pengetahuan tentang kontrasepsi dengan kepatuhan jadwal penyuntikan ulang dimana akseptor dengan tingkat pengetahuan yang tinggi belum tentu patuh pada jadwal penyuntikan ulang KB suntik. Hal ini juga dikaitkan dengan situasi pada saat penelitian dimana belum terjadi pandemic Covid-19 sehingga para akseptor dengan tingkat pengetahuan apapun tidak mengalami kendala dalam mencapai pelayanan kontrasepsi.

\section{KESIMPULAN}

Tingkat pengetahuan responden tentang Covid-19 pada akseptor KB suntik di Desa Kemasan Kabupaten Sukoharjo mayoritas dalam kategori rendah yaitu $72,5 \%$ dan sebanyak $27,5 \%$ dalam kategori tinggi. Kepatuhan akseptor dalam melaksanakan KB suntik mayoritas adalah tidak patuh 
yaitu sebanyak $75 \%$ dan sebanyak $25 \%$ responden saja yang patuh. Terdapat hubungan tingkat pengetahuan tentang Corona Virus Disease dengan kepatuhan penggunaan alat kontrasepsi suntik pada akseptor KB suntik di Desa Kemasan Kabupaten Sukoharjo ( $p$ $<0,001)$, dimana semakin tinggi tingkat pengetahuan yang dimiliki oleh akseptor maka semakin tinggi pula tingkat kepatuhan akseptor dalam melakukan kunjungan untuk penyuntikan alat kontrasepsi suntik.

\section{SARAN}

1. Petugas kesehatan di wilayah Desa Kemasan Kabupaten Sukoharjo atau Puskesmas setempat untuk meningkatkan penyuluhan kesehatan pada warga secara umum agar pengetahuan warga tentang Corona Virus Disease lebih meningkat.

2. Petugas kesehatan dan kader kesehatan agar memantau para akseptor KB suntik di wilayah Desa Kemasan agar melaksanakan KB suntik sesuai dengan jadwal yang telah ditentukan.

3. Bidan Desa lebih mendekatkan pelayanan KB suntik misalnya di Posyandu sehingga para akseptor tidak harus ke Puskesmas untuk melakukan penyuntikan ulang.

\section{DAFTAR PUSTAKA}

Andalas. 2014. Goresan Tangan Spesialis Kandungan. Sibuku Media.

https://books.google.co.id/book s/ about/ Goresan Tangan_ Spesialis_Kandungan.htm>. Diakses 25 Oktober 2020.

Aqmal, R. 2020. Pendidikan Keluarga Dan Partisipasi Masyarakat Pada Program Keluarga Berencana Di Masa Pandemi COVID- 19 Desa Keradin Kecamatan Lingga
Timur Kabupaten. 1(2), 213222. Diakses 25 Oktober 2020.

Ariana, S. 2017. Manajemen Pendidikan: Peran Pendidikan Dalam Menambah Budaya Inovatif \& Kompetitif. ANDI. Diakses 25 Oktober 2020, https://books.google.co.id/book s/ about/Manajemen Pendidikan .html>.

BKKBN. 2016. Kebijakan Program Kependudukan, Keluarga Berencana dan Pembangunan Keluarga dalam Mendukung Keluarga Sehat. PT. Bina Pustaka, Jakarta.

Daud, A., Syam, et al., ed. 2020. Penanganan Coronavirus (COVID-19) Ditinjau Dari Perspektif Kesehatan Masyarakat. Gosyen Publishing, Yogyakarta.

Febrianti. 2018. Hubungan Tingkat Pengetahuan lbu tentang Kontrasepsi Suntik dengan Kepatuhan Jadwal Penyuntikan Ulang di Bidan Praktik Mandiri Murtinawita Pekanbaru Tahun 2015. Ensiklopedia of Journal. Vol. 11 No. 1. https://media.neliti.com/media/p ublications/271826-hubungantingkat-pengetahuanibutentang-ed3843b0.pdf.

Jitowiyono, S. \& Rouf, M. A. 2019. Keluarga Berencana (KB) Dalam Perspektif Bidan. PT. Pustaka Baru, Yogyakarta.

Kementerian Kesehatan Republik Indonesia. 2020. Pedoman Pencegahan dan Pengendalian Corona Virus Deases (Covid19). Kementrian Kesehatan, 5, 178.

https://covid19.go.id/storage/ap p/media/Protokol /REV05_Pedoman_ P2_COVID19_13_Juli_2020.pdf. Diakses 27 Oktober 2020.

Khomsan, A., et al., ed. 2020. Pemikiran Guru Besar IPB Tantangan Generasi Muda Dalam Pertanian, Pangan, Dan 
Energi. IPB Press. Diakses 25 Oktober 2020, https://books.google.co.id/book s?id= tqr5DwAAQBAJ\&pg=PR4\&dq= pemikiran+guru+besar+ipb+20 20\&hl>.

Muslima, L., \& Herjanti, H. 2019. Pengukuran Faktor yang Mempengaruhi Kepatuhan Akseptor KB Suntik Ulang 1 Bulan. Serambi Saintia: Jurnal Sains Dan Aplikasi, 7(1), 3951. https://doi.org/10.32672/ jss. v7i1.991. Diakses 27 Oktober 2020.

Nasrudin, R. dan I. Haq. 2020. Pembatasan Sosial Berskala Besar (PSBB) dan Masyarakat Berpenghasilan Rendah. SALAM : Jurnal Sosial dan Budaya Syar-i. Vol. 7 No. 7. http://journal.uinjkt.ac.id/index.p hp/salam/article/view/15569.

Noriani, N.K., N.M. Nurtini dan P.R.K. Indriana. 2019. Hubungan Pengetahuan dan Motivasi Akseptor KB Suntik 3 Bulan dengan Kepatuhan Kunjungan Ulang di BPM Koriawati tahun 2017. https://www.google.com/search $? q=$ kepatuhan+akseptor $+K B+s$ untik+di+BPM+Koriawati\%2C+ Bali\%2C+sebesar+63\%2C2\%2 5. \&oq=kepatuhan+akseptor $+K$ $B+$ suntik+di+BPM+Koriawati\% $2 C+$ Bali\%2C+sebesar+63\%2C $2 \% 25 . \&$ aqs $=$ chrome. $69 i 57.111$ $1 j 0 j 15 \&$ sourceid $=$ chrome \&ie $=U$ TF-8

Notoatmojo, Soekidjo. 2011. Kesehatan Masyarakat IImu \& Seni. Rineka Cipta, Jakarta.

Purnamasari, I. dan A. E. Raharyani. 2020. Tingkat Pengetahuan dan Perilaku Masyarakat Kabupaten Wonosobo tentang Covid -19. Jurnal IImiah Kesehatan. Vol. 10 No. 1. https://ojs.unsiq.ac.id/index.php ljik/issue/view/92.
Purwanti, S. 2021. Dampak Penurunan Jumlah Kunjungan KB terhadap Ancaman Baby Boom di Era Covid-19. Jurnal Bina Cipta Husada. Vol. XVI No. 2.

Qadaruddin, M. 2020. Polemik COVID-19 \& Perubahan Sosial. IAIN Parepare Nusantara Pres. Diakses 25 November 2020, https://books.google.co.id/book s/about/Polemik COVID 19 P ERUBAHAN SOSIAL.html>.

Siswosuharjo, S. \& Chakrawati, F. 2010. Panduan Super Lengkap Hamil Sehat. Penebar Plus. Diakses 25 November 2020, https://www.penebarswadaya.c om/shop/kesehatan/sehat-dancantik/panduan-super-lengkaphamil-sehat-cd/>.

Sudarsana I Ketut, et al., E. 2020. COVID-19 Perspektif Agama dan Kesehatan. Yayasan Kita Menulis. Diakses 26 Oktober 2020,

https://kitamenulis.id/2020/06/1 8/Covid-19-perspektifpendidikan.

Undang-undang (UU) No. 10 Tahun 1992.

Kependudukan Perkembangan

Pembangunan Keluarga Sejahtera.

Wawan, A. \& Dewi, M. 2010. Teori \& Pengukuran Pengetahuan Sikap Dan Perilaku Manusia. Mulia Medika, Yogyakarta.

Yanti, et al. 2020. Community Knowledge, Attitude, and Behavior Towards Social Distancing Policy As Prevention Transmission of Covid-19 In Indonesia. JAKI (Jurnal Administrasi Kesehatan Indonesia). Volume 8.

Yuhedi, L. T. \& Kurniawati, T. 2015. Buku Ajar Kependudukan \& Pelayanan KB. Buku Kedokteran EGC, Jakarta. 